\title{
Differences in sward structure of ryegrass cultivars and impact on milk production of grazing dairy cows
}

\author{
Manuel Flores-LeSAMA ${ }^{\mathrm{a}}$, Laurent HAZARD ${ }^{\mathrm{b} *}$, Michèle BETIN ${ }^{\mathrm{b}}$, \\ Jean-Claude EMILE ${ }^{b}$
}

\footnotetext{
${ }^{a}$ Sector de Ciencias Agrarias, Universidade Federal Do Parana, CP 2959, 80001-970 Curitiba, Brazil

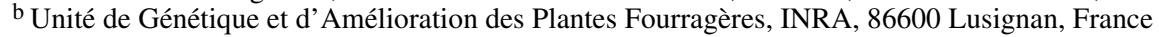

(Received 3 December 2004; accepted 9 August 2005)

\begin{abstract}
Animal trials cannot be used in routine in a forage grass-breeding programme or in a cultivar testing procedure. An alternative to these animal trials is to identify plant traits associated with a high animal production under grazing that could be used as selection criteria. For this, the effect of sward structure on milk production was studied, comparing four late-heading diploid perennial ryegrass cultivars (Lolium perenne L.) under grazing. They were rotationally strip grazed with forty-eight autumn calving dairy cows during three periods in spring 1999. Herbage allowance was $18 \mathrm{~kg} \mathrm{DM} \cdot \mathrm{cow}^{-1} \cdot \mathrm{day}^{-1}$ and the rotation interval was 3 weeks. Differences in milk production were small but significant. Cows that grazed cultivar 1 exhibited an extra milk production of $0.4 \mathrm{~kg} \cdot \mathrm{cow}^{-1} \cdot \mathrm{day}^{-1}$ than those that grazed cultivar 4 . Total biomass, digestibility and nitrogen contents were similar irrespective of the cultivar. Cultivar 4 exhibited a higher biomass per tiller but a lower tiller density, bulk density and green leaf mass in the upper layers of the sward compared to cultivar 1. Cows likely ingested more pseudostems formed by the sheath tubes and the stem growing inside grazing cultivar 4 than the others $(14 \mathrm{vs} .8 \mathrm{~cm})$. The intermediate layers of the sward, containing pseudostems, were 6.7 points less digestible than the upper layers. Therefore, the ingested herbage of cultivar 4 was likely to be less digestible and less palatable than the others.
\end{abstract}

cultivars / Lolium perenne / milk production / pasture / sward structure

Résumé - Effet variétal du ray-grass anglais sur la production laitière de vaches au pâturage. Les tests animaux ne sont pas utilisables en routine lorsqu'il s'agit de sélectionner des graminées fourragères ou d'évaluer de nouvelles variétés. L'alternative est d'identifier les caractéristiques végétales associées à un haut niveau de production animale afin de pouvoir les utiliser comme critères de sélection. Dans cette optique, l'effet de la structure du couvert de quatre variétés tardives de ray-grass anglais (Lolium perenne L.) sur la production laitière a été étudié avec des vaches au pâturage. Ces variétés ont été exploitées au pâturage tournant, chaque 3 semaines, au fil, par 48 vaches laitières. Trois périodes de pâturage ont été réalisées au cours de l'année 1999. La surface allouée aux vaches était ajustée de telle sorte que la quantité d'herbe offerte soit maintenue constante à $18 \mathrm{~kg} \mathrm{MS} \cdot \mathrm{vache}^{-1}$.jour ${ }^{-1}$. Les différences de production laitière induites par les variétés ont été faibles mais significatives. La variété 1 a entraîné une production laitière de $0,4 \mathrm{~kg} \cdot \mathrm{vache}^{-1}$.jour ${ }^{-1}$

* Corresponding author: hazard@toulouse.inra.fr 
supérieure à celle engendrée par la variété 4 . Les 4 variétés n'ont pas présenté de différence significative de biomasse totale, de digestibilité ou de teneur en azote. La variété 4 a présenté, en revanche, des talles plus longues que la variété 1 , mais de plus faibles densités de talles et de biomasse de feuille verte dans les parties supérieures du couvert. Les vaches ont ingéré une longueur plus importante de pseudotiges [gaine + tige en croissance], en pâturant plus la variété 4 que les autres variétés $(14$ vs. $8 \mathrm{~cm}$ ). Les strates intermédiaires du couvert contenant les pseudotiges présentent 6,7 points de digestibilité de moins que les strates supérieures, l'herbe ingérée par les vaches sur la variété 4 était vraisemblablement moins digestible et palatable que sur les autres variétés.

\section{Lolium perenne / pâture / production laitière / structure du couvert / variétés}

\section{INTRODUCTION}

Forage grass cultivars have been improved for increased dry matter production and disease tolerance. Forage quality (palatability, organic matter digestibility) has been taken into account in breeding programmes since in vitro digestibility methods were developed [6]. Animals have been used in preference tests in grass breeding programmes [38] but no relationship has been established between animal preference and intake in the absence of choice [14], so that selecting grass according to animal preference does not result in an increasing animal production $[20,40]$. Intake, which is considered to be a more limiting factor than digestibility under grazing $[1,4]$, is not genetically improved in breeding programmes because the effect of cultivars on animal production cannot be easily assessed. An alternative to animal trials, which cannot be used routinely in a breeding programme, is to develop indirect methods to estimate animal performance. Under grazing, animal trials should make it possible to identify grass traits associated with high animal production, which could be used as selection criteria. Very few grazing experiments were carried out to assess the effects of different cultivars on animal production [36], and most of these grazing experiments were conducted using sheep $[9,11,19,28,30]$. When conducted using dairy cows, the tests revealed little cultivar effect on their ingestive behaviour and animal performance $[3,26]$.

In a previous experiment, Emile et al. [13] found a 5\% difference in the milk production of dairy cows grazing different perennial ryegrass cultivars. No significant difference was found in the chemical composition and in vitro digestibility of dry matter between cultivars. Consequently, the $5 \%$ difference was attributed to the difference in sward structure. Sward structure, when modified by grazing management, has a strong influence on bite size [7] and herbage intake by dairy cows [33]. Since milk production under grazing is limited by a low herbage intake [27], cultivar traits affecting sward structure could have a significant influence on milk production. Herbage intake increases with herbage allowance [16] but, at a given allowance, intake is positively correlated to sward height $[5,23]$ and green leaf mass [19, 31, 32, 35]. On the contrary, pseudostems, which are formed by sheath tubes and stems growing inside, are described to act as a physical barrier within the canopy that reduce grass prehensibility during the grazing down process $[31,42]$.

In this short-term experiment, we investigated the effect of the sward structure during the spring of perennial ryegrass cultivars on milk production under grazing under the optimal conditions of a rotational grazing with three-week intervals and a high nitrogen fertilisation. Four diploid and late-heading cultivars were chosen among twenty because they had exhibited in a previous experiment (unpublished data) different sward structures varying at least in sward height and sheath height. Such differences allowed us to investigate the following hypotheses: under grazing after a given regrowth duration and at a given herbage allowance: (1) milk production is positively 
related to sward height (2) milk production is negatively correlated to pseudostem height. Each cultivar was described in terms of stem elongation, tiller density, profiles of bulk density, nitrogen concentration and digestibility in relation to milk production.

\section{MATERIALS AND METHODS}

A grazing experiment was carried out in spring 1999 at the INRA Research Centre of Lusignan, France, on four diploid perennial ryegrass cultivars (cv. 1 to 4 ), heading on 6 June, 5 June, 28 May and 29 May, respectively. The 4 cultivars were each sown on 18 September 1997 in 3 replicates $\left(4100 \mathrm{~m}^{2}\right)$ to create 12 paddocks. The sowing was in rows at $20 \mathrm{~cm}$ spacing, at $40 \mathrm{~kg} \cdot \mathrm{ha}^{-1}$. The seeds were endophyte-free. During the year of establishment, the paddocks were continuously grazed by heifers. Refusals were cut with a forage harvester and the residues were removed. The paddocks received a total of $120 \mathrm{~kg} \cdot \mathrm{ha}^{-1}$ nitrogen application as ammonium nitrate $(34.5 \% \mathrm{~N})$ in 1998 and $60 \mathrm{~kg} \mathrm{~N} \cdot \mathrm{ha}^{-1}$ in February 1999 . The three paddocks per cultivar were successively grazed during three periods from 16 to 30 April (P1), 18 May to 4 June (P2) and 17 to 21 June (P3). After grazing, each paddock was cut with a forage harvester and the herbage that has been cut was removed from the paddock. The interval between these regulation cuts and the next grazing periods was 3 weeks. After the second grazing period, $60 \mathrm{~kg} \mathrm{~N} \cdot \mathrm{ha}^{-1}$ were also applied to the grazed paddocks.

\subsection{Animals and grazing management}

At each experimental period, forty-eight Holstein dairy cows (twelve primiparous) were used. On average before periods 1, 2 and 3, days in milk were 181, 211, and 239; daily milk yield $\left(\mathrm{kg} \cdot \mathrm{d}^{-1}\right)$ was $25.1,24.2$, and 18.5; and liveweight $(\mathrm{kg})$ was 600, 624 and 637 , respectively. The cows were allotted into four similar groups. These cows were fed during the winter on a maize silagebased diet and they received concentrates according to their milk production. Three weeks before the experimental period, the cows began grazing and silage feeding was gradually decreased and eventually stopped. During the experiment, they were offered $0.5 \mathrm{~kg}$ of concentrates twice a day. Between experimental periods, the cows grazed the same cultivar of perennial ryegrass (cv. Herbie).

After a 3 week regrowth, each paddock was strip grazed using temporary fencing. The surface of each strip was adjusted every day to offer $18 \mathrm{~kg}$ herbage DM.cow ${ }^{-1} \cdot$ day $^{-1}$ based on herbage mass harvested with a motor-scythe at $7 \mathrm{~cm}$ height twice a week (Tab. I). Such herbage allowance is considered not to be limiting according to the results of Peyraud et al. [34]. Water and mineral supply was not limited.

\subsection{Animal measurements}

Individual milk production was recorded daily. Average milk production was calculated for each group of 12 cows per grazing period of a paddock. Animal care and use were carried out by a qualified staff according to the European Union rules on our approved experimental farm (French Ministry of Agriculture, agreement A86560).

\subsection{Sward measurements}

During each grazing period, pre-grazing herbage mass was estimated twice a week by cutting four strips of $0.4 \times 2 \mathrm{~m}$ per cultivar at $7 \mathrm{~cm}$ of height using a motor-scythe. Herbage biomass was weighed and a subsample was dried at $80{ }^{\circ} \mathrm{C}$ for $48 \mathrm{~h}$ to determine DM content and herbage mass.

Twice a week, extended tiller height was measured before and after grazing. At six random locations, the total height of ten tillers, their pseudostem height and their apex height within the sheath were measured. This was repeated during the second and third grazing periods. Defoliation estimates ranging from 1 (short stubble with no blade remaining after grazing) to 5 (ungrazed area) were recorded after grazing on the grazed 
strips visually divided into four rows, 25 estimates per row were given, every meter, which represented a total of 100 estimates per strip.

Sward vertical structure and bulk density were described twice a week by cutting four quadrats $(0.12 \times 0.20 \mathrm{~m})$ in each cultivar paddock. A sub-sample of 100 tillers was washed to prevent soil contamination, extended and rolled in a plastic film. This sub-sample was cut into layers of $5 \mathrm{~cm}$ starting from the base of the tillers. For each layer, blade, pseudostem and dead fraction were separated, oven-dried and weighed. The number of tillers was counted once a week in three quadrats $(0.17 \times 0.48 \mathrm{~m})$ per cultivar paddock. Tiller density and DM per layer of 100 tillers allowed the bulk density for each layer to be estimated.

The layers were bulked into three groups: the two basal layers with dead material, pseudostems and blades, the upper layers with pseudostems and blades, the upper layers with blades. The samples were milled and analysed for nitrogen (Kjeldahl method) and in vitro DM digestibility [25].

\subsection{Statistical analysis}

Differences between cultivars and groups of cows were tested for significance by analysis of variance using the GLM procedure of SAS [39] according to a random group design. Average milk production was analysed to investigate the cultivar effect, grazing period and paddock and their interactions. Sward measurements were analysed to study the cultivar effect, grazing period, sampling date nested within grazing period and their interactions. The variance between replicates (cows for animal measurements, strips, locations or quadrats for sward measurements) within a cultivar at a given date was used to calculate the error term. Extended tiller height before grazing was used as a covariate when analysing tiller height after grazing. An adjustment of the power function of bulk density versus sward depth was carried out using the NLIN procedure of SAS.

\section{RESULTS}

The differences in milk production were significant $(P<0.05)$ between cultivars and grazing periods (Tab. II). Cows grazing cv. 1 exhibited the highest total milk production: $21.3 \mathrm{~kg} \cdot \mathrm{cow}^{-1} \cdot \mathrm{day}^{-1}$ (s.e.m. $=0.1$ ) on average. Cows grazing cvs. 2, 3 and 4 respectively had a milk production of 21.0 , 20.9 and $20.8 \mathrm{~kg} \cdot \mathrm{cow}^{-1} \cdot \mathrm{day}^{-1}$ (s.e.m. = 0.1 ). Milk production decreased throughout the experiment: $24.4 \mathrm{~kg} \cdot \mathrm{cow}^{-1} \cdot \mathrm{day}^{-1}$ for the period 1, 20.2 for the period 2, 18.6 for the period 3 (s.e.m. $=0.08$ ). No significant difference between cultivars was found when analysing the three grazing periods separately.

Total herbage mass was not significantly different between cultivars but varied according to the grazing period. Herbage mass was the highest during period 2, when the reproductive stems were the longest. DM content was significantly different between grazing periods and cultivars. Among experimental periods, DM content was negatively related to herbage mass. Regardless of the period, cv. 3 had a higher DM content compared to the other cultivars (20 vs. $19 \% ; P<0.01$ ).

No significant difference was found in blade mass between experimental periods or between cultivars (Tab. II). Conversely, pseudostem mass was significantly higher $(P<0.0001)$ during the reproductive stage of period 2 (Tab. II). Differences in pseudostem mass were not significant between cultivars (Tab. II). However, the blade to pseudostem ratio was significantly different between cultivars $(P<0.001)$. Regardless of the period, cv. 1 and 2 had the mean highest ratio, 0.48 and 0.47 respectively, compared to cv. 4 (0.45) and cv. 3 (0.44).

Bulk density increased with sward depth from the top of the sward (Fig. 1). A power function $\left(y=a x^{b}\right)$ best fitted the vertical profiles of bulk density (blade and pseudostem mass per cubic meter). Cultivar and grazing period interacted significantly $(P<0.01)$ for both $a$ and $b$ parameters of the model. The increase in bulk density with sward depth was lower during period 2 than 

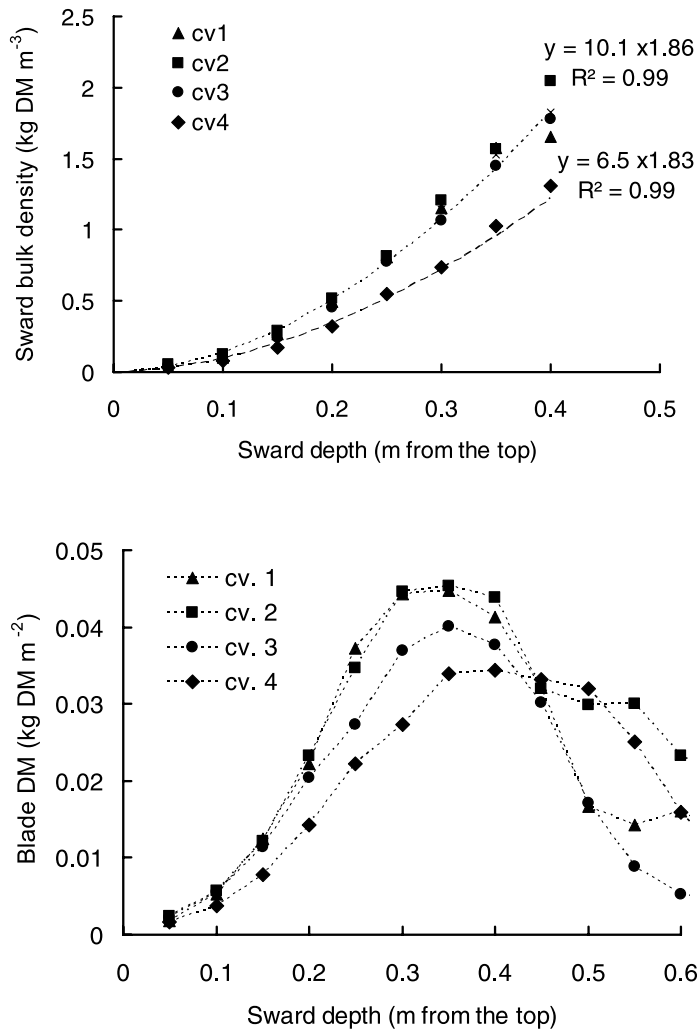

Figure 1. Profiles of bulk density from the top of the sward during grazing period 2 .

Figure 2. Profiles of blade bulk density from the top of the sward per cultivar during grazing period 2 .

during periods 1 and 3. Cv. 4 had a lower bulk density than the other cultivars at a given depth resulting in a different profile during periods 1 and 2 . No significant difference was found during period 3 .

Blade mass increased from the top of the sward to reach a maximum in the intermediate layers, 20 to $30 \mathrm{~cm}$ from the top, and then decreased in the lower layers (Fig. 2). Regardless of the period, cv. 4 had the lowest blade mass in the first $30 \mathrm{~cm}$ from the top compared to the other cultivars $(P<0.05)$. When considering period $3, \mathrm{cv}$. 2 and cv. 4 exhibited a similar pattern in blade mass profile.

Tiller density varied according to cultivar and grazing period (Tab. II), resulting in a significant interaction $(P<0.05)$. Regardless of the grazing period, cv. 4 had a lower tiller density than the other cultivars, espe- cially during period $1(P<0.05)$. Tiller density decreased sharply from period 1 to period 2 , and, during period 2 , only cvs. 2 and 4 differed significantly $(P<0.01)$. Tiller density increased between periods 2 and 3 , with cv. 3 having the highest number of tillers and being significantly different from cv. $2(P<0.05)$ and $4(P<0.01)$.

The different cultivars had different pregrazing sward heights as revealed by the significant interaction $(P<0.01)$ between cultivar and grazing period on the extended tiller height. $\mathrm{Cv} .4$ had the longest tillers regardless of the grazing period (Tab. II). During period 1, all differences were significant $(P<0.05)$ except for the difference between cv. 1 and $4(P>0.8)$. During period 2, the tillers of cv. 4 were $28 \%, 28 \%$ and $22 \%$ longer than those of cv. 2, 1 and 3 respectively $(P<0.001)$. During period 3 , cv. 4 had longer tillers than those of cv. 2 
$(P<0.01)$ and $3(P<0.001) . \mathrm{Cv} .3$ had the shortest tillers and exhibited significant differences from cv. $1(P<0.05)$.

Pseudostem length was positively related to extended tiller height before grazing in all cultivars (Tab. II). The interaction between cultivar and grazing period was highly significant $(P<0.001)$ for pseudostem length. The pseudostems in cv. 4 were significantly $(P<0.001)$ longer than in the other cultivars in both periods 1 and 2 . The cultivars showed greater variations in pseudostem heights during period 2 when the pseudostems were the longest. Cv. 3 pseudostems were significantly longer than in cv. $2(P<0.05)$ and $1(P<0.01)$. No significant difference was observed during period 3. Pseudostem height during period 1 and 2 was highly correlated to the apex height inside the sheath in all cultivars $\left(R^{2}=0.99\right)$. Elongated stems were found in the sward during periods 1 and 2 , but not during period 3 .

Since grazing was not managed according to residual herbage surface height, the extended tiller height after grazing was positively correlated to the pregrazing sward height $\left(\mathrm{R}^{2}=0.67\right)$. A significant difference $(P<0.001)$ appeared when testing cv. 4 against the other cultivars: over the 3 periods, cv. 4 had a higher extended tiller height that remained after grazing compared to the other cultivars (Tab. II). Residue biomass in the four cultivars and their heterogeneity were also described by the frequency distribution of the defoliation estimates during periods 2 and 3. During period 2, there were differences between cultivars in the frequency distribution of estimates. Ungrazed (estimate 5) and poorly grazed (estimate 4) areas represented $45 \%$ estimates attributed to cv. 4 but only $20 \%$ for cv. 1, while heavily grazed areas (estimates 1,2) constituted $64 \%$ of the frequency distribution for cv. 1 and $24 \%$ for cv. 4 . These differences were significantly different by Chi-square tests $(P<0.05)$. The differences between cultivars were not significant during period 3 .

Cultivar had no significant effect on in vitro DM digestibility and nitrogen content of the different layers of the canopy. Throughout the experiment, there was a significant interaction between grazing periods and layers in terms of digestibility but not in nitrogen content (Tab. III). However, this interaction could be neglected since it had 10 times less influence than the main factors. Digestibility and nitrogen content decreased from the top to the bottom of the sward, from 80 to $61 \%$ and from 3.3 to $1.1 \%$ respectively (Tab. III). During period 1, the plant exhibited the highest digestibility $(77 \%)$ and nitrogen content $(2.2 \%)$, while during period 2 they showed the lowest digestibility (66\%) and nitrogen content $(2.0 \%)$.

\section{DISCUSSION}

In this short-term experiment, the cultivar of perennial ryegrass grazed by dairy cows had a significant $(P<0.05)$ effect on milk production. $\mathrm{Cv} .1$ led to an extra milk production of $0.4 \mathrm{~kg} \cdot \mathrm{cow}^{-1} \cdot \mathrm{day}^{-1}$ compared to cv. 4. Milk production decreased from period 1 to period 3 in accordance with the theoretical lactation curve of the cows. Grazing periods 1 and 2 contributed most to the total difference between cultivars. These two periods corresponded to the reproductive stage of the sward, which could have increased morphological differences between cultivars [41]. The results obtained from period 3 differed from the previous periods because it was near the end of the lactating period (milk yield of 15 to $25 \mathrm{~kg} \cdot \mathrm{cow}^{-1}$. day ${ }^{-1}$ ). Moreover, the sward regrowth following the reproductive stage is known to be limited by the death of the reproductive tillers [2].

Absolute differences in milk productions were small. Perennial ryegrass is a species with high forage quality. Furthermore, cultivar effects on animal production when significant have always been small, even between old and new cultivars $[9,26]$. However, further genetic improvement should take into account that the genetic variability among registered cultivars is very limited compared to wild populations [22]. 
Table III. Means of in vitro dry matter digestibility (IVDMD) and nitrogen content of four perennial ryegrass cultivars at three different grazing periods in spring 1999.

\begin{tabular}{|c|c|c|c|c|c|c|c|c|c|c|c|c|}
\hline & \multicolumn{4}{|c|}{ Grazing period 1} & \multicolumn{4}{|c|}{ Grazing period 2} & \multicolumn{4}{|c|}{ Grazing period 3} \\
\hline & cv. 1 & cv. 2 & cv. 3 & cv. 4 & cv. 1 & cv. 2 & cv. 3 & cv. 4 & cv. 1 & cv. 2 & cv. 3 & cv. 4 \\
\hline \multicolumn{13}{|c|}{ IVDMD (\%) } \\
\hline Layer 1 & 82.5 & 82.4 & 83.0 & 82.5 & 78.0 & 74.4 & 75.9 & 76.2 & 81.6 & 82.9 & 80.4 & 83.2 \\
\hline 2 & 80.8 & 80.6 & 81.6 & 81.9 & 71.9 & 68.4 & 69.1 & 68.4 & 79.5 & 78.5 & 76.6 & 79.0 \\
\hline 3 & 67.4 & 70.9 & 68.5 & 65.7 & 51.9 & 53.2 & 51.4 & 48.9 & 66.1 & 64.7 & 63.0 & 66.5 \\
\hline \multicolumn{13}{|c|}{ Nitrogen content (\%) } \\
\hline Layer 1 & 3.39 & 3.17 & 3.48 & 3.40 & 3.49 & 3.18 & 3.74 & 3.28 & 3.15 & 2.91 & 3.03 & 3.69 \\
\hline 2 & 2.09 & 2.01 & 2.18 & 2.03 & 1.81 & 1.73 & 1.76 & 1.76 & 2.06 & 2.10 & 1.83 & 2.41 \\
\hline 3 & 1.36 & 1.24 & 1.29 & 1.18 & 0.91 & 0.89 & 0.81 & 0.81 & 1.06 & 1.19 & 0.98 & 1.43 \\
\hline
\end{tabular}

Layer 1 corresponded to the upper layer with blade, layer 2 corresponded to the layer $>10 \mathrm{~cm}$ from the soil containing a fraction of blade and pseudostem, layer 3 corresponded to the lower layer $<10 \mathrm{~cm}$ containing blade, pseudostem and dead material. The ANOVA revealed a significant effect $(P<0.0001)$ of the grazing period and of the layer for both IVDMD and Nitrogen content. The interaction was found significant $(P<0.0001)$ between grazing period and layer for IVDMD. No effect cultivar effect was found on IVDMD nor nitrogen content.

At the sward/animal interface, herbage availability and quality are the main factors influencing milk production. In our experiment, differences in milk production were likely to be due to differences in sward structure since herbage allowance and herbage digestibility were identical for all cultivars. Herbage allowance was set to $18 \mathrm{~kg}$ DM above $7 \mathrm{~cm}$ per cow per day by adjusting the surface of the one-day-paddock. Cows were not limited in herbage allowance since the residual herbage height was always above the height of $8-10 \mathrm{~cm}$ that is a threshold under which intake by grazing cows decreases [24]. Nitrogen content and digestibility of the three layers of the canopy (blades, blades + pseudostems, blades + pseudostems + dead fraction) were similar between cultivars for a given grazing period, even when reaching low values during the advanced reproductive stage of period 2 . Therefore, differences in milk production are likely related to differences in sward structure between the grazed cultivars.

Our results invalidate both of our hypotheses. Firstly, a high sward surface height does not improve milk production when comparing cultivars after a given regrowth duration because the increase in sward height was associated with a decrease in bulk density. Swards of cv. 4 always had the longest tillers but resulted in the lowest milk production. Secondly, no obvious barrier effect of the pseudostem was found. Extended sward height after grazing was significantly correlated to the value measured before grazing regardless of the pseudostem height. The animals grazed $70 \%$ of the extended sward height. Considering that dairy cows graze $35 \%$ of the extended sward height per bite [12, 42], they grazed, on average, three successive layers per day. During period 2, cows grazed a high proportion of stem. For instance, $14 \mathrm{~cm}$ of pseudostem was grazed on average in cv. 4, which corresponded to $9 \mathrm{~cm}$ of the elongated stem.

During the reproductive stage of period 1 and 2, cv. 4 had a different bulk density profile than other cultivars (Fig. 1). The bulk density profile fits a power function $\left(y=a x^{b}\right)$ and the surface integral is an estimate of the 


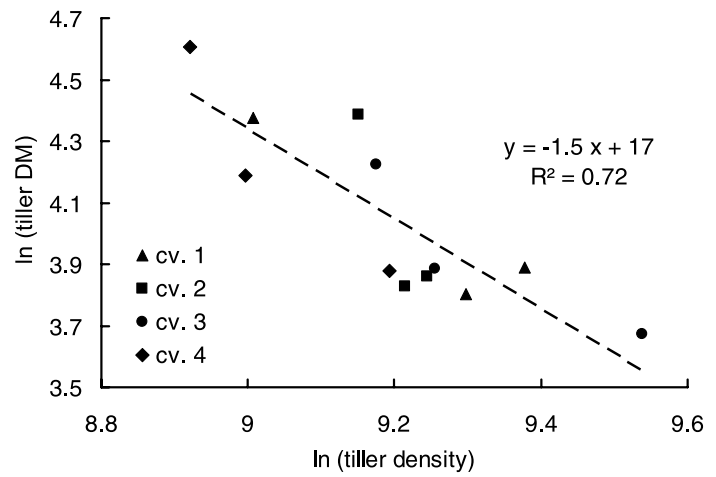

Figure 3. Relationship between natural logarithms (ln) of tiller dry matter (mg) and tiller density $\left(\times 10^{3} \mathrm{~m}^{-2}\right)$ for the three grazing periods. intake per square meter and per day. Cultivars differ in the multiplication coefficients of these equations for a given period, but not in power coefficients. Using the derived function of the power function $\left(y=a(b+1)^{-1}\right.$ $\mathrm{x}^{\mathrm{b}+1}$ ), it is possible to calculate that the grazing depth of cultivar 4 should be 1.2 fold the grazing depth of the other cultivars in order to reach the same surface integral, i.e. the same intake per surface unit. Grazing depth in cv. 4 during periods 1 and 2 exceeded that multiplication coefficient. The higher sward height and the lower bulk density of cv. 4 were possibly over-compensated for by a greater bite depth, since bite depth increases linearly with surface height [42]. Moreover, this over-compensation of low bulk density by a greater grazing depth is likely to compensate for the smaller surface of cv. 4 offered (Tab. I). Its surface was reduced by $6 \%$ during period 1 and $9 \%$ during period 2 compared to other cultivars in order to reach the same herbage allowance. This rough estimation of intake does not give any evidence of an effect of sward structure on intake. A higher grazing intensity resulting in a post-grazing sward height falling below $8 \mathrm{~cm}$, could have increased the difference of intake between cultivars.

The repartition of herbage quality along the vertical profile of the canopy could explain by itself the differences in dairy cow production. Cows grazing cv. 4 ingested more stems and pseudostems than cows grazing other cultivars. Figure 2 shows the difference in blade distribution along the sward vertical profile. $\mathrm{Cv} .4$ had a smaller blade mass in the upper layers of the sward than the others. Moreover, grazing depth was greater. During period $1,8 \mathrm{~cm}$ of the pseudostem on average were grazed in $\mathrm{cv}$. 4 but only $1 \mathrm{~cm}$ in the other cultivars. During period 2 , the quantity was even larger since $14 \mathrm{~cm}$ of the pseudostem containing $9 \mathrm{~cm}$ of the elongated stem were grazed on cv. 4 compared to $8 \mathrm{~cm}$ of the pseudostem containing $4 \mathrm{~cm}$ of stem for the three other cultivars. The difference of 1.4 points in digestibility during period 1 between the upper layer with only blade and the underneath layer with blade and pseudostem and of 6.7 points during period 2 could lead to a final difference of digestibility of the ingested herbage. Consequently, ingested herbage of cv. 4 could have been less digestible than that of the other cultivars. As a result, milk production is negatively related to the proportion of pseudostems in the grazed horizon.

The height of pseudostems and elongated stems are strictly correlated during the reproductive stage (Fig. 3). The elongated stem and the proportion of pseudostems in the grazed horizon at a given date are related to the heading date of the cultivar. However, genetic variability of sward structure occurs at a given phenological stage since the maturity of cv. 3 is similar to that of cv. 4 but with a very different sward structure. $\mathrm{Cv}$. 4 could have been grazed a few days before the other cultivars if grazing had been managed according to sward surface 
height. However, even if tiller height and pseudostem height had been identical, tiller density of cv. 4 would still have been less than that of the others. Consequently, bulk density profile of cv. 4 could have been even less favourable to milk production than that described in our experiment.

In a well-established sward, the herbage DM yield (herbage mass $>7 \mathrm{~cm}$ height) is likely to be related to the pseudostem proportion. Under such conditions, high herbage DM yield is clearly associated with tall tillers [21, 29, 37, 46]. Under the optimal rotational grazing conditions of our experiment, cv. 4 had the longest tillers and was the most productive. Tall tillers are associated with a low tiller density (Fig. 3) in accordance with the $-3 / 2$ power law or selfthinning law $[8,45]$. Density does not fully compensate for tiller mass since the slope is $-3 / 2$ and not -1 , consequently the taller the tillers, the higher the DM yield. There is an allometric relationship between tiller height and pseudostem height [10, 44]. Pseudostems contribute to support leaf area and should be well developed to support long blades in the case of high tillers. Consequently, there is a positive relationship between herbage DM yield and pseudostem height that is reinforced by the significant contribution of pseudostem and stem DM to herbage DM yield.

Long stems and pseudostems reduced the efficiency of herbage utilisation under grazing. Defoliation estimates given after grazing ranged from 1 to 5. During period 2, the estimate 5, corresponding to the refusal, represents $9 \%$ in cv. 4 and only $4 \%$ in cv. 1 (Fig. 2). Cv. 4 was more heterogeneous than the other cultivars, suggesting that some degree of selective grazing did occur. In this experiment, residual herbage was removed after each grazing period, so that the sward remained as homogeneous as possible and limiting the carry-over effects from one grazing period to another. However, more attention should be dedicated to quantifying these cumulative effects in further cultivar comparative studies. Cultivars with reduced standing pseudostem, which could increase forage grazing by cows and prevent mechanical cutting to remove refusal, are of interest to reduce production costs but also to simplify pasture management for farmers.

\section{CONCLUSION}

Cultivars that do not differ in standing biomass or in herbage quality of that total biomass could still have an impact on milk production through sward structure. As found in the present experiment, a different repartition of blades, sheaths, stems and dead material along the vertical profile of the grass canopy could induce a significant difference in milk production between cows that graze cultivars having different sward structures. Attention should be paid by the grass breeder not only to the overall cultivar DM yield and quality but also to sward structure. Moreover, sward structure should be described from the top to the ground in successive layers that make sense from the grazing animal. Consequently, breeding perennial ryegrass in order to achieve increased herbage utilisation under grazing should result in different cultivars than the marketed cultivars which have been selected for potential DM yield. Pseudostem and stem contribution to DM yield should be reduced as much as possible. Gowen et al. [15] have already shown the advantage of grazing later heading grass cultivar to increase milk production at grazing. French farmers have done so by preferentially using very late flowering cultivars to graze non-stemmy swards as long as possible during the spring since summer grazing is uncertain regardless of the stem presence. However, within a maturity group, genetic variability should be exploited in the perennial ryegrass breeding program. Selecting for a shorter stem would improve cultivar potential under grazing and under seed production as well because of greater resistance to lodging [18]. Another method of genetic improvement would be to select 
ryegrass according to higher digestibility of pseudostems and stems [17]. A radical solution to the presence of stem in the grass canopy, suggested by Wilkins et al. [43], is to genetically engineer a mechanism for flowering to occur only during seed production.

\section{ACKNOWLEDGEMENTS}

This work was supported by a grant of the French Ministry of Agriculture. We thank Scott Laidlaw for his comments, Fabien Surault, Khalid El Brinsii, Marie-Françoise Pissard for technical assistance.

\section{REFERENCES}

[1] Armstrong R.H., Robertson E., Hunter E.A., The effect of sward height and its direction of change on the herbage intake and performance of weaned lambs grazing ryegrass swards, Grass Forage Sci. 50 (1995) 389-398.

[2] Bahmani I., Thom E.R., Matthew C., Hooper R.J., Lemaire G., Tiller dynamics of perennial ryegrass cultivars derived from different New Zealand ecotypes: effects of cultivar, season, nitrogen fertiliser, and irrigation, Aust. J. Agr. Res. 54 (2003) 803-817.

[3] Barret P.D., McGilloway D.A., Laidlaw A.S., Mayne C.S., The effect of sward structure as influenced by ryegrass genotype on bite dimensions and short-term intake rate by dairy cows, Grass Forage Sci. 58 (2003) 2-11.

[4] Beerepoot L.J., Agnew R.E., Breeding for improved herbage quality in perennial ryegrass, Seeds of progress BGS Occ. Symp., Nottingham, UK, 31, 1997, pp. 135-145.

[5] Burlison A.J., Hodgson J., Illius A.W., Sward canopy structure and the bite dimensions and bite weight of grazing sheep, Grass Forage Sci. 46 (1991) 29-38.

[6] Casler M.D., Vogel K.P., Accomplishments and impact from breeding for increased forage nutritional value, Crop Sci. 39 (1999) 12-20.

[7] Casey I.A., Laidlaw A.S., Brereton A.J., McGilloway D.A., Watson S., The effect of bulk density on bite dimensions of cattle grazing microswards in the field, J. Agr. Sci. (2005) 109-121.

[8] Chapman D.F., Lemaire G., Morphogenetic determinants of plant regrowth after defoliation, Proc. XVII Int. Grassland Congr., Palmertson North, New-Zealand, 1993, pp. 95104.

[9] Clark H., Relative performance of three cv. of late-heading perennial ryegrass continuously stocked by ewes and lambs, Proc. XVII Int. Grassland Congr., Palmertson North, NewZealand, 1993, pp. 456-457.

[10] Davies A., Evans M.E., Exley J.K., Regrowth of perennial ryegrass as affected by simulated sheaths, J. Agr. Sci. (Camb.) 101 (1983) 131137.

[11] Davies A., Comparative sheep production and herbage characteristics on four perennial ryegrass varieties in the uplands, Grass Forage Sci. 42 (1987) 233-239.

[12] Demment M.W., Peyraud J.L., Laca E.A., Herbage intake at grazing a modelling approach, Proc. IVth Int. Symp. Nutrition of Herbivores, Paris, France, 1995, pp. 497-526.

[13] Emile J.C., Hazard L., Betin M., Monnerie C., Cultivar effect in perennial ryegrass on milk production of dairy cows, Proc. 18th General Meeting European Grassland Federation, Aalborg, Denmark, 2000, pp. 235-237.

[14] Gillet M., Noël C., Comment comparer l'ingestibilité en vert des variétés de graminées ? Premiers résultats, Agronomie 3 (1983) 867-872.

[15] Gowen N., O’Donovan M., Casey I., Rath M., Delaby L., Stakelum G., The effect of grass cultivars differing in heading date and ploidy on the performance and dry matter intake of spring calving dairy cows at pasture, Anim. Res. 52 (2003) 321-336.

[16] Greenhalgh J.F.D., Reid G.W., Aitken J.N., Florence E., The effects of grazing intensity on herbage consumption and animal production. I. Short term effects in strip-grazed dairy cows, J Agr. Sci. (Camb.) 24 (1966) 98-103.

[17] Groot J.C.J., Neuteboom J.H., Lantinga E.A., Deinum B., Elements for modelling in vitro digestibility of grass on the basis of morphological and physiological plant characteristics, in: Groen A.F., Van Bruchem J. (Eds.), Utilisation of local feed resources in dairy cattle, Wageningen Press, Wageningen, 1996, pp. 137-138.

[18] Hampton J.G., Clemence T.G.A., Hebblethwaite P.D., Nitrogen studies in Lolium perenne grown for seed. IV. Response of amenity types and influence of a growth regulator, Grass Forage Sci. 38 (1983) 97-105.

[19] Hazard L., De Moraes A., Betin M., Traineau R., Emile J.C., Perennial ryegrass cultivar effects on intake of grazing sheep and feeding value, Ann. Zootech. 47 (1998) 117-125.

[20] Hazard L., Ghesquière M., Limites d'une évaluation des variétés de ray-grass anglais au pâturage basée sur le choix des animaux et des différences de hauteur d'herbe, Fourrages 154 (1998) 159-171. 
[21] Hazard L., Ghesquière M., Productivity under contrasting cutting regimes of perennial ryegrass selected for short and long leaves, Euphytica 95 (1997) 295-299.

[22] Hazard L., Ghesquière M., Betin M., Breeding for adaptation in perennial ryegrass (Lolium perenne). I. Assessment of yield under contrasting cutting frequencies and relationships with leaf morphogenesis components, Agronomie 14 (1994) 259-266.

[23] Laca E.A., Ungar E.D., Sligman N., Demment M.W., Effects of sward height and bulk density on bite dimensions of cattle grazing homogeneous swards, Grass Forage Sci. 47 (1992) 13-16.

[24] Le Du Y.L.P., Combellas J., Hodgson J., Baker R.D., Herbage intake and milk production by grazing dairy cows. 2 . The effects of level of winter feeding and daily herbage allowance, Grass Forage Sci. 34 (1979) 249260.

[25] Lila M., Barrière Y., Traineau R., Mise au point d'étude d'un test enzymatique de la digestibilité des fourrages pauvres ou riches en amidon, Agronomie 6 (1986) 85-291.

[26] McCallum D.A., Thomson N.A., The effect of different perennial ryegrass cultivars on dairy animal performance, Proc. N.-Z. Soc. Anim. Prod. 54 (1994) 87-90.

[27] Meijs J.A.C., Herbage intake by grazing dairy cows, $\mathrm{PhD}$ thesis, Wageningen Agricutural University, Wageningen, 1981.

[28] Munro J.M.M., Davies D.A., Evans W.B., Scurlock R.V., Animal production evaluation of herbage varieties. 1. Comparison of Aurora with Frances, Talbot and Melle perennial ryegrass when grown alone and with clover, Grass Forage Sci. 47 (1992) 259-273.

[29] Nelson C.J., Asay K.H., Sleper D.A., Mechanisms of canopy development of tall fescue genotypes, Crop Sci. 17 (1977) 449-452.

[30] Orr R.J., Cook J.E., Champion R.A., Penning P.D., Rook A.J., Intake characteristics of perennial ryegrass varieties when grazed by sheep under continuous stocking management, Euphytica 134 (2003) 247-260.

[31] Parga J., Peyraud J.L., Delagarde R., Effect of sward structure and herbage allowance on herbage intake by grazing dairy cows, in: Grazing management, the principles and practice of grazing for profit and environmental gain in temperate grassland system, Harrogate, British Grassland Society (Ed.), 2000, pp. 61-66.

[32] Penning P.D., Parsons A.J., Orr R.J., Hooper G.E., Intake and behaviour responses by sheep to changes in sward characteristics under rotational grazing, Grass Forage Sci. 49 (1994) 476-486
[33] Peyraud J.L., Gonzalez-Rodrigez A., Relations between grass production, supplementation and intake in grazing dairy cows, Proc.

18th General Meeting European Grassland Federation, Aalborg, Denmark, 2000, pp. 269282.

[34] Peyraud J.L., Comeron E.A., Wade M.H., Lemaire G., The effect of daily herbage allowance, herbage mass and animal factors upon herbage intake by grazing dairy cows, Ann. Zootech. 45 (1996) 201-217.

[35] Prache S., Intake rate, intake per bite and time per bite of lactating ewes on vegetative and reproductive swards, Appl. Anim. Behav. Sci. 52 (1997) 53-65.

[36] Reed K.F.M., Improved grass cultivars increase milk and meat production - a review, New-Zeal. J. Agr. Res. 37 (1994) 277-286.

[37] Rhodes I., Mee S.S., Changes in dry matter yield associated with selection for canopy characters in rye-grass, Grass Forage Sci. 35 (1980) 35-39.

[38] Rogers H.H., Breeding for digestibility and palatability of grasses, Seed Tr. Re. 16 (1964) 97-105.

[39] SAS Institute Inc., SAS/STAT user's guide, version 6, SAS Institute ed., Cary, USA, 1989.

[40] Sleper D.A., Breeding tall fescue, Plant Breeding Review 3 (1985) 313-342.

[41] Taube F., Growth characteristics of contrasting varieties of perennial ryegrass (Lolium perenne L.), J. Agron. Crop Sci. 165 (1990) 159-170.

[42] Wade M.H., Factors affecting the availability of vegetative Lolium perenne to grazing dairy cows with special references to sward characteristics, stocking rate and grazing method, $\mathrm{PhD}$ Thesis, Université de Rennes I, ${ }^{\circ}$ 615, 1991.

[43] Wilkins P.W., Allen D.K., Mytton L.R., Differences in nitrogen use efficiency of perennial ryegrass varieties under simulated rotational grazing and their effects on nitrogen recovery and herbage nitrogen content, Grass Forage Sci. 55 (2000) 69-76.

[44] Wilson R.E., Laidlaw A.S., The role of the sheath tube in the development of expanding leaves in perennial ryegrass, Ann. Appl. Biol. 106 (1985) 385-391.

[45] Yoda K., Kira T., Ogawa H., Hozumi K., Selfthinning in overcrowded pure stands under cultivated and natural conditions (intraspecific competition among higher plants XI), J. Biol. 14 (1963) 107-129.

[46] Zarrough K., Nelson C.J., Regrowth of genotypes of tall fescue differing in yield per tiller, Crop Sci. 20 (1980) 541-544. 